\title{
Lack of the serum and glucocorticoid-inducible kinase SGK1 attenuates the volume retention after treatment with the PPAR $\gamma$ agonist pioglitazone
}

\author{
Ferruh Artunc • Diana Sandulache • Omaima Nasir • \\ Krishna M. Boini • Björn Friedrich • Norbert Beier • \\ Edith Dicks • Sven Pötzsch • Karin Klingel • \\ Kerstin Amann • Bonnie L. Blazer-Yost • \\ Wolfgang Scholz • Teut Risler • Dietmar Kuhl • \\ Florian Lang
}

Received: 28 August 2007 /Revised: 6 November 2007 / Accepted: 14 November 2007 /Published online: 3 January 2008

(C) Springer-Verlag 2007

\begin{abstract}
PPAR $\gamma$-agonists enhance insulin sensitivity and improve glucose utilization in diabetic patients. Adverse effects of PPAR $\gamma$-agonists include volume retention and edema formation. Recent observations pointed to the ability of PPAR $\gamma$ agonists to enhance transcription of the serum and glucocorticoid-inducible kinase SGK1, a kinase that is genomically upregulated by mineralocorticoids and stimulates various renal channels and transporters including the renal epithelial $\mathrm{Na}^{+}$channel ENaC. SGK1 has been proposed to mediate the volume retention after treatment with PPAR $\gamma$ agonists. To test this hypothesis, food containing the PPAR $\gamma$ agonist pioglitazone $(0.02 \%$, i.e., approxi-
\end{abstract}

F. Artunc $\cdot$ D. Sandulache $\cdot$ O. Nasir $\cdot$ K. M. Boini $\cdot$ F. Lang $(\bowtie)$

Department of Physiology,

University of Tübingen,

Gmelinstr. 5,

72076 Tübingen, Germany

e-mail: florian.lang@uni-tuebingen.de

F. Artunc $\cdot$ B. Friedrich $\cdot$ T. Risler

Department of Internal Medicine IV,

University of Tübingen,

Otfried-Müller-Str. 10,

72076 Tübingen, Germany

N. Beier $\cdot$ W. Scholz

Diabetes Research DA, Merck KGaA,

Frankfurter Str. 250,

64271 Darmstadt, Germany

E. Dicks $\cdot$ S. Pötzsch

Central Analytical R\&D, ZD-A/ZFA, Merck KGaA,

Frankfurter Str. 250,

64271 Darmstadt, Germany mately $25 \mathrm{mg} / \mathrm{kg}$ bw/day) was administered to gene-targeted mice lacking SGK1 $\left(\mathrm{sgkl}^{-/}, n=12\right)$ and their wild-type littermates $\left(s g k l^{+/+}, n=12\right)$. According to in situ hybridization, quantitative reverse transcriptase-polymerase chain reaction (RT-PCR) and immunofluorescence, treatment with pioglitazone significantly increased renal SGK1 mRNA and protein expression in $s g k 1^{+/+}$mice. The treatment increased body weight significantly in both, $s g k 1^{+/+}$mice $(+2.2 \pm 0.3 \mathrm{~g})$ and $s g k^{--}$mice $(+1.3 \pm 0.2 \mathrm{~g})$, and decreased hematocrit significantly in $s g k 1^{+/+}$mice $(-6.5 \pm 1.0 \%)$ and $s g k 1^{-/}$mice $(-3.1 \pm 0.6 \%)$. Both effects were significantly $(p<0.05)$ more pronounced in $s g k 1^{+/+}$mice. According to Evans Blue

K. Klingel

Department of Molecular Pathology, University of Tübingen,

Liebermeisterstr. 8,

72076 Tübingen, Germany

K. Amann

Department of Pathology,

University of Erlangen,

Krankenhausstr. 12,

91054 Erlangen, Germany

B. L. Blazer-Yost

Biology Department,

Indiana University-Purdue University at Indianapolis,

723 West Michigan St.,

Indianapolis, IN 46202, USA

D. Kuhl

Department of Biology, Chemistry, and Pharmacy,

Free University Berlin,

Takusstr. 9,

14195 Berlin, Germany 
distribution, pioglitazone increased plasma volume only in $s g k l^{+/+}$mice (from $50.9 \pm 3.9$ to $63.7 \pm 2.5 \mu \mathrm{l} / \mathrm{g}$ bw) but not in $s g k^{-/}$mice (from $46.8 \pm 3.8$ to $48.3 \pm 5.2 \mu \mathrm{l} / \mathrm{g} \mathrm{bw}$ ). Pioglitazone decreased aldosterone plasma levels and blood pressure and increased leptin plasma levels in both genotypes. We conclude that SGK1 contributes to but does not fully account for the volume retention during treatment with the PPAR $\gamma$ agonist pioglitazone.

Keywords Serum and glucocorticoid inducible kinase . Plasma volume - Aldosterone - Leptin · Volume retention . PPAR $\gamma$ agonists

\section{Introduction}

Peroxisome proliferator-activated receptor gamma (PPAR $\gamma$ ) is a ligand-dependent transcription factor that belongs to the nuclear receptor family [4]. PPAR $\gamma$ is highly expressed in white adipose tissue where it controls adipocyte differentiation and lipid storage [4]. Pharmacological activation of PPAR $\gamma$ by thiazolidinediones such as pioglitazone or rosiglitazone has been shown to enhance insulin sensitivity and to lower plasma glucose concentrations particularly in patients with insulin resistance [11, 32, 42]. Accordingly, PPAR $\gamma$ agonists are now well-established drugs widely used in the treatment of type 2 diabetes [37, 39]. PPAR $\gamma$ agonists have further been shown to decrease proteinuria [5] and counteract renal fibrosis [30, 50].

The use of the PPAR $\gamma$ agonists has, however, been impeded by their volume retaining properties $[18,22,49]$. In patients with congestive heart failure (CHF), treatment with PPAR $\gamma$ agonists was associated with decompensation and occurrence of pulmonary edema [35]. Thus, the use of PPAR $\gamma$ agonists is not recommended in patients with CHF [45].

PPAR $\gamma$ is expressed in kidney and is particularly abundant in the inner medulla [20]. Therefore, the volume retaining effect of PPAR $\gamma$-agonists may be due to stimulation of the epithelial sodium channel $(\mathrm{ENaC})$ in the distal nephron [26]. Accordingly, gene-targeted mice with a collecting duct-specific deletion of PPAR $\gamma$ are apparently protected against PPAR $\gamma$ agonists-induced fluid retention [51].

Two mechanisms have been invoked to mediate the stimulation of $\mathrm{ENaC}$ and the subsequent fluid retaining by $\operatorname{PPAR} \gamma$ activation. On the one hand, PPAR $\gamma$ agonists were found to upregulate mRNA levels of SCNN1G encoding for the gamma subunit of $\mathrm{ENaC}$ in a mouse inner medullary collecting duct cell line [19]. On the other hand PPAR $\gamma$ agonists have been shown to stimulate the transcription of the serum and glucocorticoid-inducible kinase SGK1 [22], which, in turn, was suggested to enhance the surface expression of $\mathrm{ENaC} \alpha$ [22]. In three well-established cell culture models of the renal principal cell type, PPAR $\gamma$ agonists did not alter basal or insulin-stimulated $\mathrm{ENaC}$ activity and may thus be effective through additional mechanisms [36], which, at least in theory, could be similarly sensitive to SGK1.

SGK1 has originally been identified as a gene under transcriptional control of glucocorticoids [15] but later found to be genomically stimulated by mineralocorticoids $[10,31,34]$. SGK1 is expressed in the aldosterone-sensitive distal nephron [31], where it stimulates the epithelial $\mathrm{Na}^{+}$ channel ENaC [1, 10, 13, 29, 34]. Beyond that, SGK1 has been shown to stimulate a wide variety of further renal and extrarenal ion channels and transporters [28]. Gene-targeted mice lacking SGK1 $\left(\mathrm{sgkl}^{-1-}\right)$ excrete similar amounts of salt under regular salt intake but cannot adequately decrease renal $\mathrm{NaCl}$ elimination after exposure to salt-depleted diet. As a result, salt deplete diet leads to marked decrease of glomerular filtration rate and blood pressure in $s g \mathrm{kl}^{-/-}$ mice [46].

The present study aimed to define the in vivo role of SGK1 in the volume retaining effects of PPAR $\gamma$ agonists. To this end, $s g k^{-/-}$mice and their wild-type littermates $\left(s g k l^{+/+}\right)$ were treated with the PPAR $\gamma$ agonist pioglitazone.

\section{Materials and methods}

Animal experimentation

All animal experiments were conducted according to the guidelines of the American Physiological Society and the German law for the welfare of animals and were approved by local authorities.

Mice deficient in SGK1 $\left(\mathrm{sgkl}^{-/}\right)$and their wild-type littermates $\left(\mathrm{sgkl}^{+/+}\right)$were generated and bred as previously described $[24,46]$. They were fed a control diet (C1000, Altromin, Lage, Germany) and had free access to tap water. After a control period, the food pellets were replaced by custom-made pellets containing $0.2 \mathrm{~g} / \mathrm{kg}$ pioglitazone with otherwise identical composition (C1000 + Pioglitazone, Altromin, Lage, Germany). The drug intake approached $20-30 \mathrm{mg} / \mathrm{kg}$ bw/day, a dosage previously shown to be effective [47].

For the evaluation of renal $\mathrm{Na}^{+}$excretion, body weight and fluid and food intake, $s g k l^{-/-}$and $s g k I^{+/+}$mice were placed individually in metabolic cages (Techniplast Hohenpeissenberg, Germany) for 24-h urine collection with free access to tap water and the respective diet [40]. Mice were studied before treatment, during the first 8 days and after 4 weeks of pioglitazone treatment. The inner wall of the metabolic cages was siliconized and urine was collected under water-saturated oil. For comparison, $s g k 1^{-1-}$ and 
$s g k I^{+/+}$mice were fed the control diet $\mathrm{C} 1000$ and followed over 4 weeks.

To study the role of ENaC inhibition in pioglitazoneinduced volume retention, $s g k l^{-/-}$and $s g k l^{+/+}$mice were treated for 8 days with the $\mathrm{ENaC}$ blocker triamterene (Sigma, Taufkirchen, Germany) in the drinking water (200 mg/l, pH 4, light-protected) and the pioglitazonecontaining diet. The triamterene intake approached 35$40 \mathrm{mg} / \mathrm{kg} \mathrm{bw} /$ day, a dosage previously shown to be effective [21].

To obtain blood specimens, animals were lightly anesthetized with diethylether (Roth, Karlsruhe, Germany), and about $150 \mu$ of blood was withdrawn into heparinized hematocrit capillaries by puncturing the retro-orbital plexus. Hematocrit was determined by centrifugation. Blood loss was replaced with $200 \mu \mathrm{l} 0.9 \% \mathrm{NaCl}$ subcutaneously, and the animals were allowed to recover for 2 weeks.

Expression of SGK1 was determined early (3-4 days) after treatment to elucidate, whether alterations in SGK1 transcript levels or protein expression precede volume expansion. Body weight was determined daily from the beginning, and plasma hormone levels, plasma volume, and blood pressure, 2-4 weeks after the beginning of the treatment to disclose the effect of chronic PPAR $\gamma$ activation on the respective functional parameters.

\section{Determination of plasma volume}

Plasma volume was assessed by dye dilution using Evans Blue (Sigma, Taufkirchen, Germany). Mice were anesthetized with diethylether and 30-50 $\mu$ of an Evans Blue stock solution $(3 \mathrm{mg} / \mathrm{ml}$ in $0.9 \% \mathrm{NaCl})$ was injected intravenously into the left retro-orbital plexus using a 30-gauge insulin syringe (BD micro-fine, Heidelberg, Germany). The exact applied volume was determined by weighing the syringe before and after injection. Repeated blood samples $(20-25 \mu \mathrm{l})$ were drawn fom the right retroorbital plexus during superficial diethylether anesthesia after 30, 60, and $100 \mathrm{~min}$, which yielded a volume of $10 \mu \mathrm{l}$ plasma after centrifugation. Absorbance was measured at $620 \mathrm{~nm}$ against blank mouse serum after recovery in $90 \mu \mathrm{l}$ phosphate-buffered saline (PBS tablets, Invitrogen, Karslruhe, Germany). Plasma concentrations of Evans Blue were calculated using the stock solution dissolved in mouse serum as a standard. To correct for the clearance of Evans Blue during distribution time, linear regression of the log transformed concentrations was applied to calculate the $y$-intercept which represents the imaginary concentration of Evans Blue in its final distribution volume [16]. $r^{2}$ approached $0.94 \pm 0.07$ (SD). Division of the applied dose of Evans Blue (in $\mathrm{mg}$ ) by the $y$-intercept (in $\mathrm{mg} / \mathrm{ml}$ ) resulted in the distribution volume of Evans Blue which was normalized for body weight.
Measurement of $\mathrm{Na}^{+}$, creatinine, aldosterone, and leptin concentrations

Plasma and urinary concentrations of $\mathrm{Na}^{+}$were measured by flame photometry (AFM 5051, Eppendorf, Germany) and plasma aldosterone concentrations using a commercial RIA kit (Demeditec, Kiel, Germany). Plasma and urinary creatinine concentrations were measured using an enzymatic colorimetric method (creatinine PAP, Lehmann, Berlin, Germany). Plasma leptin levels were determined using an ELISA kit (Linco, St. Charles, USA).

\section{Determination of systolic blood pressure}

Systolic arterial blood pressure was determined by the tailcuff method (IITC, Model 179, CA, USA) under control diet and 3 weeks after treatment with pioglitazone. As reviewed recently [33], the tail-cuff approach to determine arterial blood pressure requires certain precautions to reduce the stress of the animals, including appropriate training of the mice over multiple days and adequate prewarming to dilate the tail artery. The animals were placed in a heated chamber at an ambient temperature of $30^{\circ} \mathrm{C}$ for $15 \mathrm{~min}$. For each animal, 10-20 blood pressure traces were recorded in one session. The readings from 3 days were then averaged to obtain a mean blood pressure under the respective treatment. All recordings and data analysis were done using a computerized data acquisition system and software (PowerLab 400 and Chart 4, both AdInstruments, CO, USA). All measurements were done by one person (FA) during a defined time (between 2 and 4 P.M.).

\section{Determination of plasma concentrations of pioglitazone}

Quantitative determination of pioglitazone in plasma was performed using an high performance liquid chromatography (HPLC) tandem mass spectrometry (MS/MS) assay after protein precipitation with methanol. A homolog was used as internal standard (IS). Plasma samples were cleared from any precipitates by centrifugation at $13,700 \times g$ for $5 \mathrm{~min}$. After adding $15 \mu \mathrm{l}$ of the working solution containing IS $(0.5 \mu \mathrm{g} / \mathrm{ml}$ in acetonitrile/water $60 / 40 \mathrm{v} / \mathrm{v})$ to $5 \mu \mathrm{l}$ of the plasma samples, proteins were precipitated by addition of $150 \mu \mathrm{l}$ methanol. After centrifugation at $3,000 \times g$ for $5 \mathrm{~min}, 30 \mu \mathrm{l}$ of the supernatant was recovered and diluted by adding $750 \mu 1$ acetonitrile/water $(60 / 40 v / v)$. An aliquot of $10 \mu \mathrm{l}$ was injected. The HPLC system consisted of an HTC PAL autosampler (CTC Analytics, Zwingen, Switzerland) and an Agilent 1100 HPLC equipment (Agilent Technologies, Böblingen, Germany). Chromatography was performed on a Chromolith SpeedROD ${ }^{\circledR}$ RP-18e, ID $3 \mathrm{~mm}$ using gradient elution. The mobile phase consisted of two components: solvent A 
( $0.1 \%$ formic acid) and solvent B (acetonitrile). At a flow rate of $0.8 \mathrm{ml} / \mathrm{min}$, an isocratic period of $0.6 \mathrm{~min}$ at $100 \% \mathrm{~A}$ was followed by a linear gradient ( 0 to $90 \% \mathrm{~B} / 0.6$ to $1.5 \mathrm{~min}$ ) and a period from 1.5 to $3.0 \mathrm{~min}$ at $90 \% \mathrm{~B}$. Equilibration was achieved by flushing the column with $100 \%$ acetonitrile over $30 \mathrm{~s}$ at a flow rate of $2.0 \mathrm{ml} / \mathrm{min}$. Detection was performed using an Applied Biosystems (Forster City, CA, USA) 4000 Qtrap triple quadrupole mass spectrometer operated in the positive turbo-ion-spray mode by applying multiple reaction monitoring (MRM). The used mass transition for pioglitazone was 357.1 to $134.1 \mathrm{amu}$.

In situ hybridization

In situ hybridization experiments were performed to investigate whether pioglitazone increases SGK1 transcript levels in the kidney. Expression was studied in $\mathrm{s} g k 1^{+/+}$mice after a 3-day treatment with pioglitazone-containing diet corresponding to the highest slope of body weight gain. Control mice were treated over 3 days with control diet $(n=3$ each). Kidneys were harvested after retrograde perfusion with phosphate-buffered $4 \%$ paraformaldehyde $(\mathrm{pH}$ 7.4) through cannulation of the infrarenal aorta. Anesthesia was achieved with tribromethanol $(250 \mathrm{mg} / \mathrm{kg}$ bw i.p.) and ketamin (50 $\mathrm{mg} / \mathrm{kg}$ bw i.m.).

Perfused kidneys were kept in paraformaldehyde overnight and then transferred to phosphate-buffered saline. After embedding in paraffin-dewaxed paraffin, $5 \mu \mathrm{m}$ tissue sections were hybridized as described $[25,27]$. The mixture contained ${ }^{35}$ S-labeled RNA antisense murine SGK1 probe of $1,400 \mathrm{bp}$ length $(500 \mathrm{ng} / \mathrm{ml})$ in $10 \mathrm{mM}$ Tris $-\mathrm{HCl}$, $\mathrm{pH} 7.4 / 50 \%(v / v)$ deionized formamide $/ 600 \mathrm{mM} \mathrm{NaCl} /$ $1 \mathrm{mM}$ EDTA $/ 0.02 \%$ polyvinylpyrrolidon/0.02\% Ficoll/ $0.05 \%$ bovine serum albumin $/ 10 \%$ dextrane sulfate/ $10 \mathrm{mM}$ dithiothreitol/denatured sonicated salmon sperm DNA $200 \mu \mathrm{g} / \mathrm{ml} / \mathrm{rabbit}$ liver tRNA $100 \mu \mathrm{g} / \mathrm{ml}$. Hybridization with RNA probes proceeded at $42^{\circ} \mathrm{C}$ for $18 \mathrm{~h}$. Slides were then washed and incubated for $1 \mathrm{~h}$ at $55^{\circ} \mathrm{C}$ in $2 \times$ standard saline citrate. Nonhybridized single-stranded RNA probes were digested by RNase A $(20 \mu \mathrm{g} / \mathrm{ml})$ in $10 \mathrm{mM}$ Tris- $\mathrm{HCl}, \mathrm{pH} 8.0 / 0.5 \mathrm{M} \mathrm{NaCl}$ for $30 \mathrm{~min}$ at $37^{\circ} \mathrm{C}$. Tissue slide preparations were autoradiographed for 3 weeks and stained with hematoxylin/eosin. Control hybridizations were performed with the corresponding $\alpha-{ }^{35} \mathrm{~S}$-labeled murine SGK1 sense RNA probe. Sufficiently strong staining required exposure periods of $>14$ days, which resulted in considerable background activity, as apparent from seemingly luminal staining.

\section{Quantitative real-time PCR}

To quantify SGK1 transcript levels in the kidney, treated and untreated $\mathrm{sgkl}^{+/+}$mice were killed after 3 days of pioglitazone or control treatment ( $n=10-11$ each), and the kidneys were rapidly frozen on liquid nitrogen. PPAR $\gamma$ transcript levels were quantified in untreated $s g k 1^{-1-}$ and $s g k 1^{+/+}$mice $(n=7$ each). Automated disruption and homogenization of frozen tissue of whole kidneys was performed using the MagNa Lyser Instrument ${ }^{\mathrm{TM}}$ (Roche Diagnostics, Mannheim, Germany). Cleared cell lysate was transferred for further RNA purification (RNAeasy Mini Kit, Qiagen, Hilden, Germany). Subsequently $1 \mu \mathrm{g}$ of total RNA was reverse transcribed to cDNA utilizing the reverse transcription system (Bioscience, USA) with oligo(dT) primers according to the manufacturer's protocol. To determine SGK1 and PPAR $\gamma$ transcript levels, quantitative real-time PCR with the LightCycler System ${ }^{\circledR}$ (Roche Diagnostics, Mannheim, Germany) was applied using the primers $5^{\prime}$ TGTCTTGGGGCTGTCCTGTATG 3' (forward) and 5' GCTTCTGCT GCTTCCTTCACAC $3^{\prime}$ (reverse) for mSGK1, and 5' CTGTTATGGGTGAAACTCTGGGAG 3' (forward) and 5' ATAGGCAGTGCATCAGCGAA 3' (reverse) for mPPAR $\gamma$ [48] yielding products with $406 \mathrm{bp}$ (mSGK1) and $72 \mathrm{bp}$ length (mPPAR $\gamma)$. PCR reactions were performed in a final volume of $20 \mu \mathrm{l}$ containing $2 \mu \mathrm{l}$ cDNA, $2.4 \mu \mathrm{l} \mathrm{MgCl}_{2}(3 \mu \mathrm{M}), 1 \mu \mathrm{l}$ primermix $(0.5 \mu \mathrm{M}$ of both primers), $2 \mu \mathrm{l}$ cDNA Master SybrGreen I mix (Roche Molecular Biochemicals, Mannheim, Germany), and $12.6 \mu \mathrm{l}$ DEPC-treated water. The transcript levels of the housekeeping gene GAPDH were determined for each sample using a commercial primer kit (Search LC, Heidelberg, Germany). PCR reactions for GAPDH were performed in a final volume of $20 \mu \mathrm{l}$ containing $2 \mu \mathrm{l}$ cDNA, $2 \mu \mathrm{l}$ primer mix (Search LC, Heidelberg, Germany), $2 \mu \mathrm{l}$ cDNA Master Sybr Green I mix (Roche Molecular Biochemicals, Mannheim, Germany) and $14 \mu \mathrm{l}$ DEPCtreated water. The target DNA was amplified during 35 cycles of $95^{\circ} \mathrm{C}$ for $10 \mathrm{~s}, 68^{\circ} \mathrm{C}$ for $10 \mathrm{~s}$, and $72^{\circ} \mathrm{C}$ for $16 \mathrm{~s}$, each with a temperature transition rate of $20^{\circ} \mathrm{C} / \mathrm{s}$, a secondary target temperature of $58^{\circ} \mathrm{C}$, and a step size of $0.5^{\circ} \mathrm{C}$. Melting curve analysis was performed at $95^{\circ} \mathrm{C}, 0 \mathrm{~s}$; $58^{\circ} \mathrm{C}, 10 \mathrm{~s} ; 95^{\circ} \mathrm{C}, 0 \mathrm{~s}$ to determine melting temperatures of primer dimers and the specific PCR products. Melting curve analysis confirmed the amplified products. Finally, results were calculated as a ratio of the target vs house keeping gene GAPDH transcripts.

\section{Immunofluorescence}

For the analysis of SGK1 protein expression in the kidney, $s g k I^{+/+}$and $s g k 1^{-/-}$mice were killed after 3 days of pioglitazone or control treatment $(n=3$ each) and the kidneys were rapidly frozen on liquid nitrogen. For comparison, mice treated with a low-salt diet (C1036, Altromin, Lage, Germany) for 4 days were killed $(n=2$ each). Frozen sections $(3 \mu \mathrm{m})$ were fixed in acetone 
$\left(10 \mathrm{~min} ;-20^{\circ} \mathrm{C}\right)$, air-dried and incubated in Tris buffer for 5 min. Then, blocking was performed with normal goat serum (blotto, 1:5, $45 \mathrm{~min}$ ). Afterwards, the primary antibody (rabbit anti-SGK1, 1:50) was applied $\left(1 \mathrm{~h} ; 37^{\circ} \mathrm{C}\right)$ and the sections were washed in Tris buffer $(3 \times 5 \mathrm{~min})$. Polyclonal monospecific antibodies against the SGK1 protein were raised by a commercial antibody service (Dr. Pineda, Berlin, Germany) as previously described [25]. Briefly, rabbits were immunized with an oligopeptide (N-terminally cysteine-linked to hemocyanin) encoding the amino acids 128-146 of mouse and human SGK1 (GeneBank accession nos. AF205855 and AX002570), respectively. Purified IgG fractions were tested for monospecificity by immunoblot of lysates from HEK 293 cells transfected with hSGK1. Afterwards, the secondary antibody (goat anti-rabbit, Alexa 488, 1:200) was applied for 30 min. $11 \beta$ steroid dehydrogenase was probed with a commercially available sheep anti-11 $\beta$ HSD antibody (AB 1296, Chemicon) and a secondary biotinylated anti-sheep antibody with subsequent detection by Streptavidin-Alexa 568. DAPI was used to stain nuclei $(1: 1,000$ in distilled water for $5 \mathrm{~min})$ followed by rinsing in Tris buffer $(3 \times$
5 min). Finally, sections were covered with mowiol and analyzed.

\section{Statistical analysis}

Data are provided as means $\pm \mathrm{SEM} ; n$ represents the number of independent experiments. All data were tested for normality using the Kolmogorov-Smirnow test and, for significance, using two-tailed paired or unpaired Student $t$ test and Welch's correction or ANOVA, where required, using GraphPad InStat version 3.00 for Windows 95, GraphPad Software, San Diego California USA, http:// www.graphpad.com. A $p$ value less than 0.05 was considered statistically significant. Linear regression was also calculated utilizing GraphPad InStat version 3.00.

\section{Results}

Quantitative reverse transcriptase-polymerase chain reaction (RT-PCR) revealed similar PPAR $\gamma$ transcript levels in kidneys from $s g k 1^{+/+}$and $s g k 1^{-/}$mice. Absolute PPAR $\gamma$ mRNA a

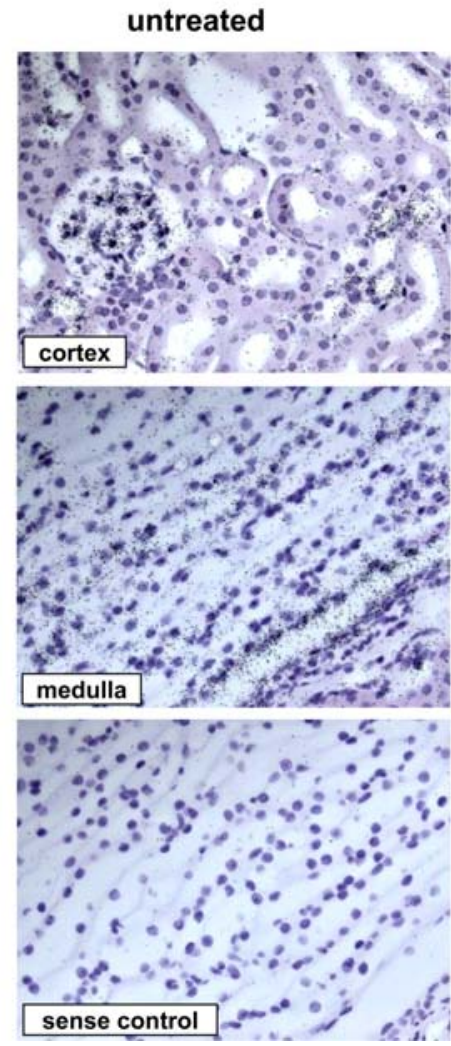

Fig. 1 Effect of pioglitazone on renal SGK1 transcript levels. a In situ hybridization showing kidney tissue of cortex (150-fold magnification) and medulla (250-fold magnification) probed with radiolabeled mSGK1 antisense. b, c Arithmetic means \pm SEM $(n=10-11$ each group) of absolute GAPDH and SGK1 copies and the ratio of SGK1 b

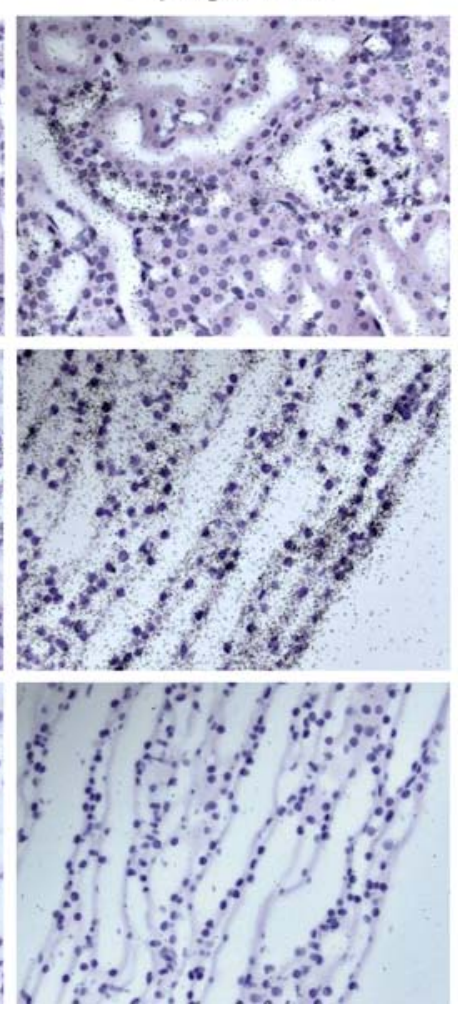

\section{c}
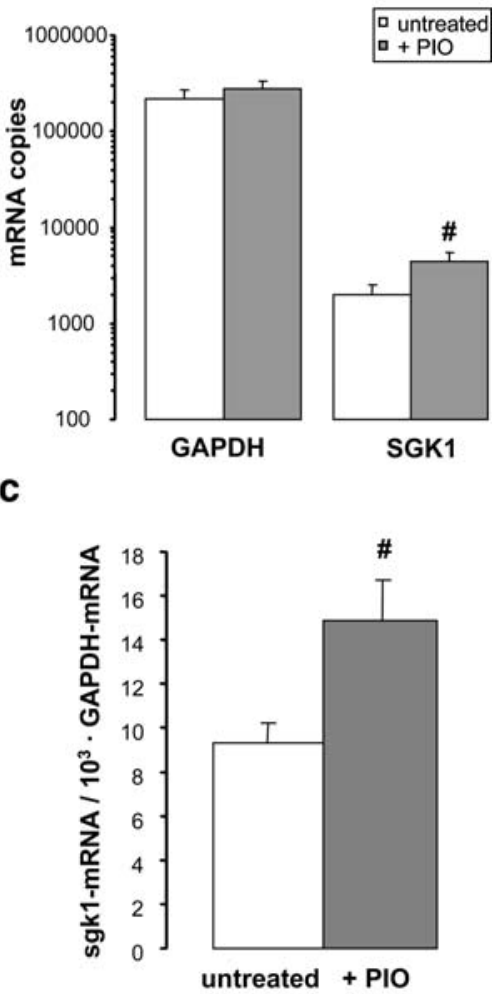

transcript levels over GAPDH transcript levels in treated (closed column) and untreated (open column) $s g k 1^{+/+}$animals. Number sign indicates significant difference between control and pioglitazone treatment 
levels in whole kidneys were $15 \pm 3$ copies in $s g k 1^{-/}(n=7)$ and $16 \pm 8$ copies in $s g k 1^{+/+}$mice $(n=7)$. Normalized for GAPDH transcript levels, the expression was $0.11 \pm 0.07$ copies $/ 10^{3}$ GAPDH in $s g k 1^{-/}$and $0.11 \pm 0.05$ copies $/ 10^{3}$ GAPDH in $s g k l^{+/+}$mice. Similarly, plasma concentrations of pioglitazone, as determined by HPLC, were not significantly different between the genotypes. After a 10-day treatment, plasma concentrations were $15.4 \pm 0.4 \mu \mathrm{M}$ in $s g k 1^{+/+}$mice and $12.2 \pm 2.5 \mu \mathrm{M}$ in $s g k 1^{-/-}$mice $(n=3$ each). Similar values were obtained after a 4-week treatment $\left(11.3 \pm 1.5 \mu \mathrm{M}\right.$ in $s g k 1^{+/+}$mice and $10.1 \pm 0.9 \mu \mathrm{M}$ in $s g k 1^{-/}$mice, $n=6$ each).

To determine, whether pioglitazone influences the transcript levels of SGK1, renal tissue was analyzed in $s g k 1^{+/+}$mice by in situ hybridization and quantitative RTPCR after a 3-day treatment with pioglitazone. As shown in Fig. 1a, pioglitazone treatment increased SGK1 mRNA abundance in the collecting duct of the renal medulla. In the sections of renal cortex, SGK1 expression tended to be stronger in the distal tubules and connecting ducts of treated mice, whereas no difference was visible between treated and untreated animals in glomeruli and proximal tubules. According to quantitative RT-PCR, pioglitazone treatment significantly increased SGK1 transcript levels in whole kidneys $(1,989 \pm 528$ copies in untreated, $4,474 \pm 1047$ copies in treated mice) without significantly affecting GAPDH mRNA levels $(218,828 \pm 51,606$ copies in untreated, 280,563 $\pm 55,101$ copies in treated mice, Fig. 1b). Expressed as a ratio of SGK1 over GAPDH, SGK1 transcript levels were induced by a factor of 1.7 (Fig. 1c). The increase in SGK1 transcript levels was paralleled by an increased SGK1 protein expression as evidenced by enhanced immunofluorescence in kidney sections from pioglitazone-treated $s g k 1^{+/+}$mice (Fig. 2). Staining was a

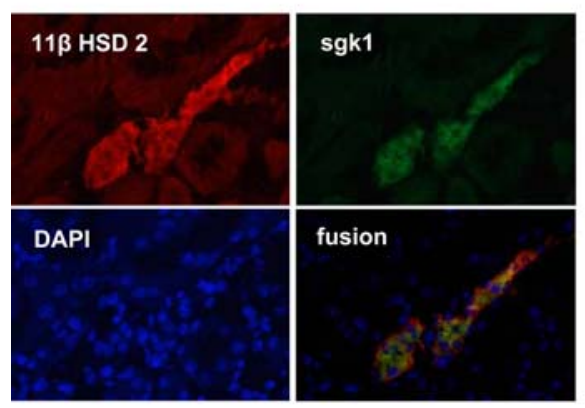

b
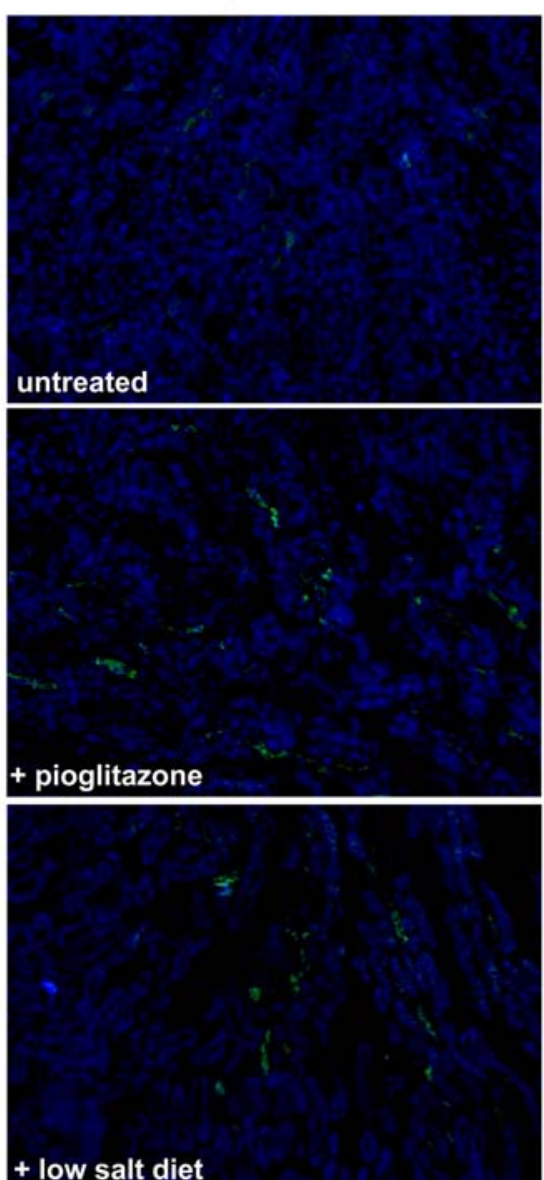

$\operatorname{sgk1} \%$
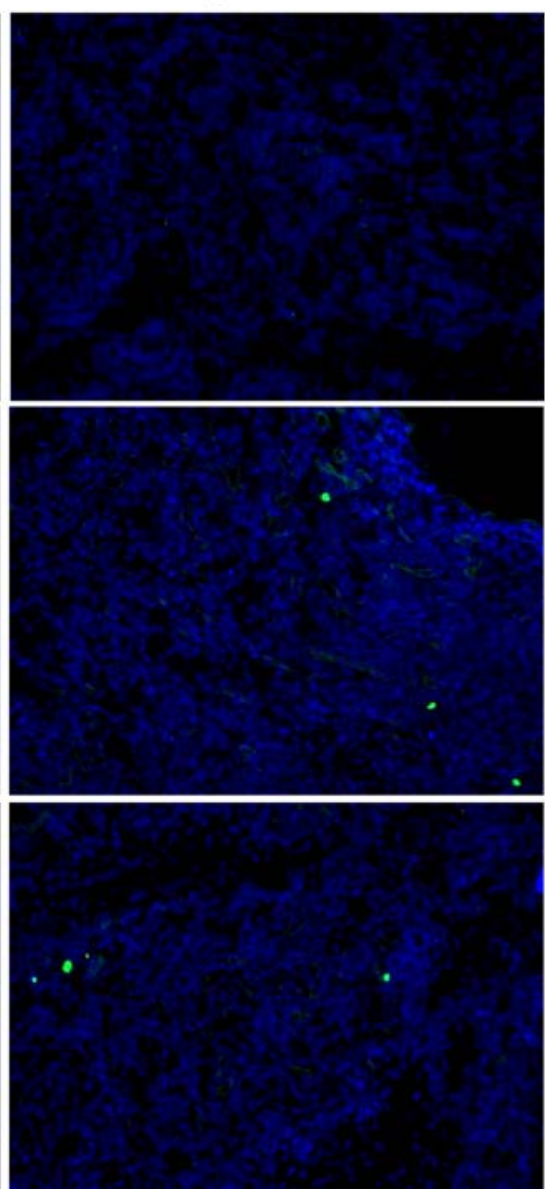

with anti-SGK1 antibody (green fluorescence) from $s g k 1^{+/+}$and $s g k 1^{-/}$mice treated with control diet, pioglitazone-containing diet for 3 days or low salt diet for 4 days (tenfold magnification). Nuclei are stained blue with DAPI
Fig. 2 Effect of pioglitazone on renal SGK1 protein expression. a Immunofluorescence of kidney sections with antibodies directed against $11 \beta$-hydroxysteroid dehydrogenase type 2 (red fluorescence) and SGK1 (green fluorescence) in the distal nephron. Nuclei are stained blue with DAPI. b Immunofluorescence of kidney sections 
confined to the distal nephron as confirmed by colocalization with $11 \beta$-hydroxysteroid dehydrogenase type 2 . The intensity of the staining after pioglitazone treatment was similar to that obtained in kidneys from mice treated with a low-salt-diet, a maneuver-stimulating aldosterone secretion and SGK1 protein expression. In kidneys from $s g k l^{-/}$ mice, no specific staining was obtained.

If pioglitazone treatment was followed by extracellular volume expansion, then the treatment should increase body weight. As illustrated in Fig. 3, body weight indeed increased during the treatment in both, $s g k 1^{+/+}$and $s g k 1^{-/}$mice. However, the increase of body weight was significantly more pronounced in $s g k 1^{+/+}$mice than in $s g k 1^{-/-}$mice both after 8-day $(+1.5 \pm 0.2 \mathrm{~g}$, vs $+1.0 \pm 0.2 \mathrm{~g}, n=12$ each $)$ and 4-week $(+2.2 \pm 0.3 \mathrm{~g}$, vs $+1.3 \pm 0.2 \mathrm{~g}, n=12$ each; Fig. 3a) treatment. During control experiments, no appreciable net body weight gain was observed after 8 days or 4 weeks (Fig. 3a and b). After simultaneous treatment with the $\mathrm{ENaC}$ blocker triamterene and pioglitazone, body weight was decreased in both genotypes to a similar extent during the first 3 days (Fig. 3a). After that, $s g k l^{-/}$mice continued to lose weight, whereas $s g k 1^{+/+}$mice restored their body weight and returned to their baseline weight.

Extracellular volume expansion should further increase plasma volume and, thus, decrease hematocrit. Pioglitazone treatment indeed decreased the hematocrit significantly in both, $s g k 1^{+/+}$and $s g k 1^{-/-}$mice (Table 1). The effect was, however, again significantly more pronounced in $s g k 1^{+/+}$ mice $(-6.5 \pm 1.0 \%, n=12)$ than in $s g k 1^{-/}$mice $(-3.1 \pm$ $0.6 \%, n=12)$ after 4 weeks of treatment. Plasma $\mathrm{Na}^{+}$concentration increased significantly in $s g k l^{+/+}$mice and tended to increase in $s g k 1^{--}$mice (Table 1).

To assess plasma volume directly, a dye dilution method using Evans Blue was applied. The dye tightly binds to plasma proteins (mainly albumin) and is thus a reliable indicator for plasma volume. As illustrated in Fig. 4, pioglitazone treatment increased significantly the ratio of plasma volume/body weight in $s g k 1^{+/+}$mice, but not in $s g k 1^{-/}$mice.

Extracellular volume expansion should decrease aldosterone release. As reported earlier [46], plasma aldosterone concentration was higher in $s g k 1^{-/-}$than in $s g k 1^{+/+}$mice before pioglitazone administration (Fig. 5). Pioglitazone treatment significantly decreased plasma aldosterone values in both genotypes. However, plasma aldosterone levels remained significantly higher in $s g k l^{-/-}$mice after treatment. The decrease of plasma aldosterone concentration tended to be larger in $s g k 1^{+/+}$mice than in $s g k l^{-/-}$mice, a difference, however, not reaching statistical significance.

Even though pioglitazone treatment induced extracellular volume expansion, it significantly decreased blood pressure from $112 \pm 4$ to $95 \pm 4 \mathrm{mmHg}$ in $s g k l^{+/+}$mice (by $-14.3 \pm$ $3.7 \mathrm{mmHg}, n=12$ ) and from $102 \pm 4$ to $90 \pm 2 \mathrm{mmHg}$ in $s g k 1^{-/}$mice (by $-19.2 \pm 4.8 \mathrm{mmHg}, n=12$ ). The decrease of blood pressure tended to be larger in $s g k 1^{-/-}$than in

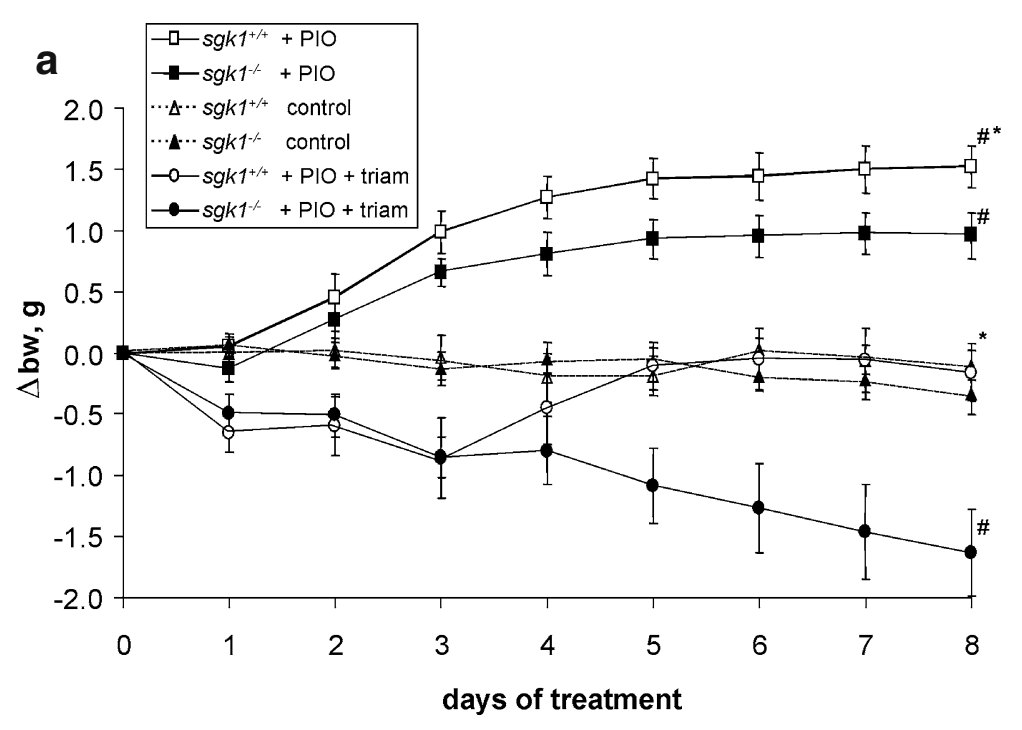

b

Fig. 3 Alterations of body weight after pioglitazone treatment. a Arithmetic means \pm SEM $(n=9-12)$ of body weight of $s g k 1^{-/}$mice (closed symbols) and $s g k 1^{+/+}$mice (open symbols) within the first 8 days of control, pioglitazone (PIO) or pioglitazone + triamterene $(\mathrm{PIO}+$ triam) treatment. Number sign indicates significant difference between control and pioglitazone treatment. Asterisk indicates signif-

icant difference between $s g k 1^{-/-}$vs $s g k 1^{+/+}$mice. For clarity, symbols for significance were only depicted in the body weight at the last day of treatment (day 8). b Arithmetic means \pm SEM $(n=9-12)$ of the alterations of body weight after 28 days of pioglitazone or control treatment in $s g k 1^{-/}$mice (closed bars) and $s g k 1^{+/+}$mice (open bars) 
Table 1 Biometric parameters before and after pioglitazone treatment

\begin{tabular}{|c|c|c|c|c|}
\hline \multirow[t]{2}{*}{ Parameter } & \multicolumn{2}{|l|}{$\operatorname{sgk} 1^{+/+}$} & \multicolumn{2}{|l|}{$\operatorname{sgk1^{-/-}}$} \\
\hline & Control & Treatment & Control & Treatment \\
\hline Body Weight (g) & $26.2 \pm 1.2$ & $28.3 \pm 1.1^{\mathrm{a}}$ & $24.7 \pm 1.3$ & $25.9 \pm 1.3^{\mathrm{a}}$ \\
\hline Food intake $(\mathrm{g} / 24 \mathrm{~h})$ & $3.37 \pm 0.2$ & $3.91 \pm 0.3^{\mathrm{a}}$ & $3.69 \pm 0.2$ & $3.93 \pm 0.2$ \\
\hline Fluid Intake (ml/24 h) & $3.95 \pm 0.5$ & $4.88 \pm 0.7^{\mathrm{a}}$ & $3.85 \pm 0.3$ & $4.13 \pm 0.3$ \\
\hline Urinary output (ml/24 h) & $1.75 \pm 0.3$ & $1.85 \pm 0.3$ & $1.75 \pm 0.2$ & $1.80 \pm 0.2$ \\
\hline Hematocrit $(\%)$ & $54.6 \pm 0.9$ & $48.1 \pm 0.9^{\mathrm{a}}$ & $52.1 \pm 0.4$ & $49.1 \pm 0.6^{\mathrm{a}}$ \\
\hline$[\mathrm{Na}+]$ plasma $(\mathrm{mM})$ & $149 \pm 2$ & $157 \pm 3^{\mathrm{a}}$ & $154 \pm 2$ & $158 \pm 2$ \\
\hline 24h-creatinine clearance $(\mu \mathrm{l} / \mathrm{min})$ & $114 \pm 13$ & $110 \pm 10$ & $148 \pm 25$ & $95 \pm 13$ \\
\hline $\begin{array}{l}\text { Urinary } \mathrm{Na}+\text { excretion } \\
(\mu \mathrm{mol} / 24 \mathrm{~h})\end{array}$ & $234 \pm 17$ & $316 \pm 22^{\mathrm{a}}$ & $270 \pm 24$ & $282 \pm 22$ \\
\hline Fractional excretion $\mathrm{Na}^{+}(\%)$ & $0.94 \pm 0.12$ & $1.72 \pm 0.16^{\mathrm{a}}$ & $1.01 \pm 0.15$ & $1.44 \pm 0.16^{\mathrm{a}}$ \\
\hline
\end{tabular}

Arithmetic means \pm SEM ( $n=12$ each) of body weight, food and fluid intake, hematocrit, plasma $\mathrm{Na}^{+}$concentrations, renal excretion of $\mathrm{Na}^{+}$and creatinine clearance in SGK1 knockout mice $\left(\mathrm{sgk1^{-/- }}\right)$ and their wild-type littermates $\left(\mathrm{sgk} 1^{+/+}\right)$before and after 4 weeks of pioglitazone treatment,

${ }^{a}$ Indicates significant difference between control and treatment with pioglitazone

$s g k 1^{+/+}$mice, a difference, however, not reaching statistical significance (Fig. 6).

As leptin is released from adipocytes, plasma leptin concentrations increase with adipocyte mass. Pioglitazone treatment increased plasma leptin concentrations in both genotypes to a similar extent (Fig. 7).

\section{Discussion}

The present observations disclose an influence of the serum and glucocorticoid inducible kinase SGK1 on the volumeretaining effect of pioglitazone. Pioglitazone treatment increased renal SGK1 mRNA and protein expression, which is apparently required for the full effect of the PPAR $\gamma$ agonist on extracellular fluid volume.

Differences in the observed effects between $s g k 1^{+/+}$and $s g k 1^{-/}$mice were not attributable to differences in PPAR $\gamma$ expression or pioglitazone plasma levels. The latter were in the lower micromolar range $(10-15 \mu \mathrm{M})$, which is comparable to levels measured in volunteers after oral ingestion of $30 \mathrm{mg}$ pioglitazone $(3 \mu \mathrm{M}$; [44]). At those concentrations, pioglitazone does increase extracellular fluid volume, as previously shown for PPAR $\gamma$ agonists $[18,22,49]$.

According to the present study, SGK1 may contribute to, but does not fully account for, the fluid retaining effects of pioglitazone. Volume retention was estimated from body a

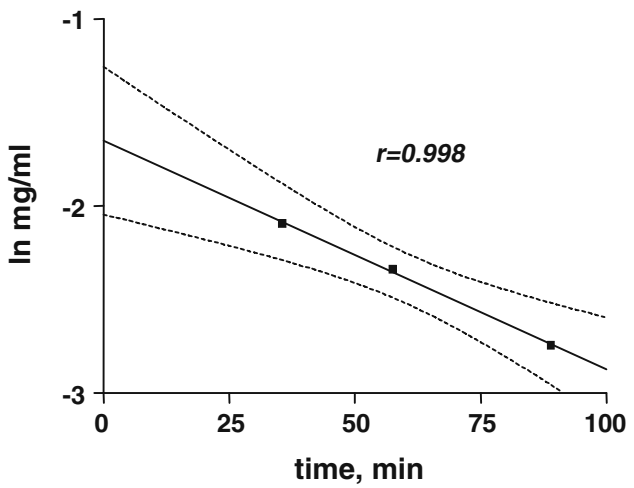

Fig. 4 Plasma volume determined using Evans Blue. a Representative experiment demonstrating the time-dependent decay of Evans Blue plasma concentration. b Arithmetic means \pm SEM $(n=9$ each group) of relative plasma volume (per gram body weight) of $s g k 1^{-/}$ b

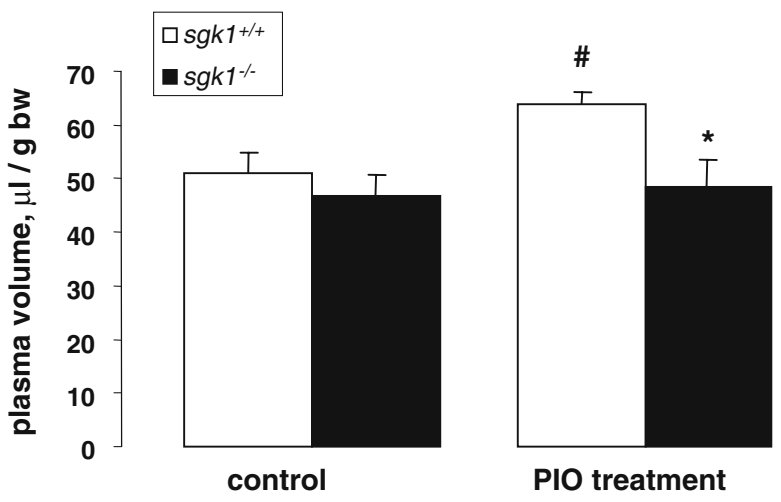

mice (closed columns) and $s g k 1^{+/+}$mice (open columns) before and 3 weeks after pioglitazone treatment. Asterisk indicates significant difference between $s g k 1^{-/}$vs $s g k 1^{+/+}$mice. Number sign indicates significant difference between control and treatment with pioglitazone 
Fig. 5 Plasma aldosterone concentrations. a Arithmetic means \pm SEM $(n=12$ each group) of plasma aldosterone concentration in $s g k 1^{--}$mice (closed columns) and $s g k 1^{+/+}$ mice (open columns) before and 2 weeks after pioglitazone treatment. Number sign indicates significant difference between control and treatment with pioglitazone, Asterisk indicates significant difference between $s g k 1^{-/-}$vs $s g k 1^{+/+}$mice. b Relative change of plasma aldosterone levels \pm SEM $(n=12$ each group) a

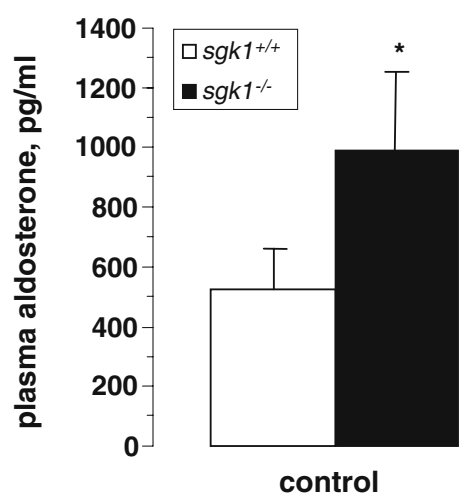

b

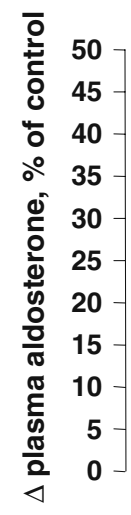

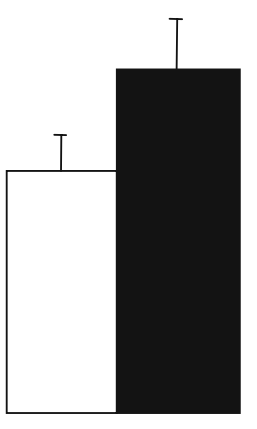

PIO treatment weight, hematocrit, plasma aldosterone concentrations, and by direct determination of the plasma volume. Whereas the first three parameters pointed to some volume retention in $s g k 1^{-/}$mice, plasma volume increased significantly only in $s g k 1^{+/+}$mice. The differences may reflect methodological limitations in the analysis of volume retention. The effects of pioglitazone on body weight, hematocrit, and plasma aldosterone concentration in $\mathrm{s} g k 1^{-/-}$mice point to SGK1-independent effects of pioglitazone on sodium and fluid reabsorption. $\mathrm{ENaC}$ activity and expression was found to be directly stimulated by pioglitazone in a mouse collecting duct cell line [19], but not in other studies using CCD principal cell lines [36]. Treatment with triamterene prevented the body weight gain in $s g k 1^{+/+}$mice, an observation indeed pointing to the involvement of $\mathrm{ENaC}$ in pioglitazone-induced volume retention. $\mathrm{ENaC}$ is regulated by SGK1, which stimulates $\mathrm{ENaC}$ expression and activity $[1,10,13,29,34]$. Interestingly, $s g k 1^{-/}$mice under combined treatment were more susceptible to the diuretic action of triamterene and continued to lose weight over the treatment period. The sensitivity of $s g k 1^{-/}$mice to triamterene mice clearly points to SGK1 independent ENaC activity. Beyond that, the possibility must be considered that the volume retaining activity of SGK1 is not exclusively due to stimulation of $\mathrm{ENaC}$. As a matter of fact, in vitro experiments disclosed the ability of SGK1 to stimulate a wide variety of carriers and channels [28] including the renal tubular $\mathrm{Na}^{+}, \mathrm{K}^{+}, 2 \mathrm{Cl}^{-}$cotransporter [29].

The actions of the PPAR $\gamma$ agonist pioglitazone on the distal nephron strongly resemble the actions of aldosterone, a

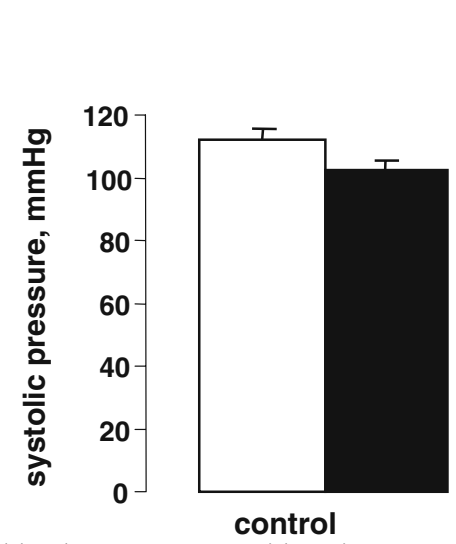

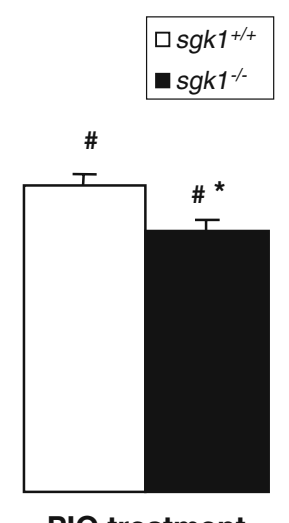

PIO treatment b

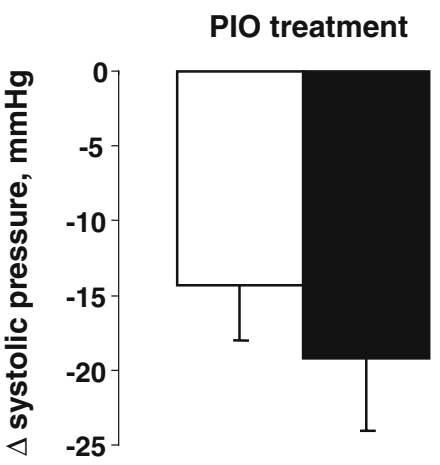

Fig. 6 Systolic blood pressure. a Arithmetic means \pm SEM $(n=12$ each group) of systolic blood pressure in $s g k 1^{-/-}$(closed columns) and $s g k 1^{+/+}$mice (open columns) before (control) and 3 weeks after pioglitazone treatment. Number sign indicates significant difference between control and treatment with pioglitazone, Asterisk indicates significant difference between $s g k 1^{-/}$vs $s g k 1^{+/+}$mice. b Arithmetic means \pm SEM ( $n=12$ each group) of the change of systolic blood pressure in $s g k 1^{-/-}$(closed columns) and $s g k 1^{+/+}$mice (open columns) after 3 weeks pioglitazone treatment 
Fig. 7 Plasma leptin concentrations. Arithmetic means \pm SEM $(n=12$ each group) of plasma leptin concentrations before and after 1 and 2 weeks of treatment in $\mathrm{sgkI^{-/- }}$ mice (closed columns) and $s g k 1^{+/+}$mice (open columns) mice. Number sign indicates significant difference between control and treatment with pioglitazone
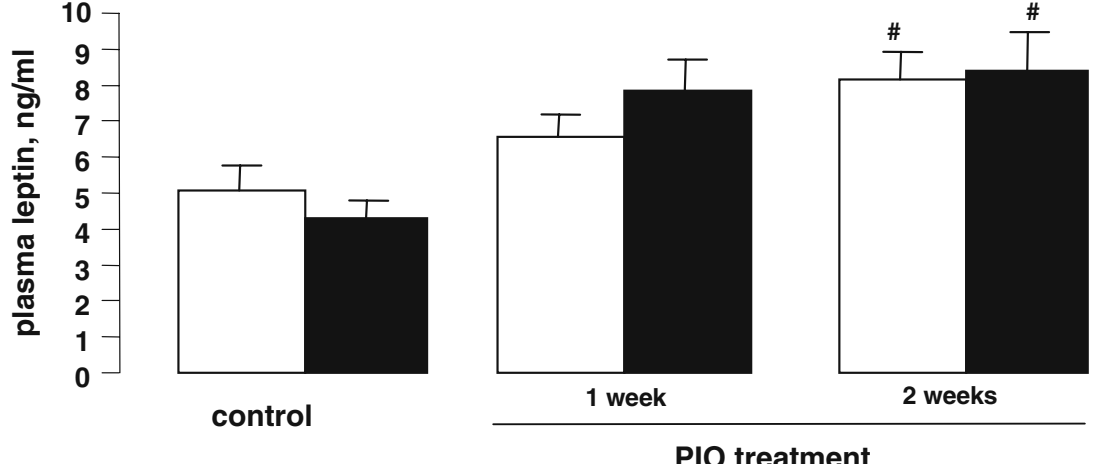

which also exerts both, SGK1-independent direct [3] and SGK1-dependent indirect effects on $\mathrm{ENaC}$ expression and activity $[1,10,13,29,34]$. As part of a counter-regulation to the pioglitazone-induced volume retention, endogenous aldosterone levels were suppressed. However, plasma aldosterone levels remained significantly higher in $s g k 1^{-/-}$ mice under pioglitazone treatment.

The administration of pioglitazone sensitizes tissues for the action of insulin $[11,32,42]$. The effects of aldosterone and insulin or IGF-1 may be additive [17]. Insulin stimulates SGK1 and is thus expected to enhance ENaC activity and renal $\mathrm{Na}^{+}$reabsorption [6-8]. SGK1 contributes to the regulation of renal $\mathrm{Na}^{+}$excretion by aldosterone, insulin, and IGF-1. As the effect of aldosterone is only partially dependent on the presence of SGK1, the effects of aldosterone and SGK1 may be additive. However, ADH or insulin do not further stimulate $\mathrm{ENaC}$ in cells expressing constitutively active SGK1 [2].

Along those lines, acute intravenous application of insulin (under euglycemic conditions) significantly decreased fractional urinary $\mathrm{Na}^{+}$excretion without affecting blood pressure and GFR in $\operatorname{sgk} 1^{+/+}$mice, an effect significantly blunted in $\mathrm{sgk}^{-/-}$mice [23]. Those experiments demonstrate a critical role of SGK1 in insulininduced renal $\mathrm{Na}^{+}$retention. In contrast, PPAR $\gamma$ agonists showed no effect on basal or insulin-stimulated $\mathrm{ENaC}$ activity [36].

The salt retaining effects of PPAR $\gamma$ agonists were expected to increase blood pressure. The opposite is observed, i.e., decrease of blood pressure. A hypotensive effect of PPAR $\gamma$ agonists is similarly observed in clinical studies and may be due to a vasodilating effect of PPAR $\gamma$ agonists [38]. Even though the blood pressure lowering effect is apparent in both, $s g k 1^{-/-}$and $s g k I^{+/+}$mice, it is more pronounced in $s g k 1^{-1-}$ mice. Thus, SGK1 counteracts the blood pressure-lowering effect of pioglitazone.

The salt-retaining effect of SGK1 is expected to impact on blood pressure control. As a matter of fact, SGK1 expression is deranged in the salt sensitive Dahl rat [14]. Moreover, moderately enhanced blood pressure values are observed in individuals carrying a variant of the SGK1 gene, affecting some $3-5 \%$ of unselected Caucasians [9, 43]. Interestingly, the gene variant is associated with enhanced insulin sensitivity of blood pressure [43].

SGK1 does not only participate in electrolyte balance by its influence on renal elimination, but mediates at least, in part, the effect of mineralocorticoids on salt appetite [41]. Thus, SGK1 plays a dual role in mineralocorticoidregulated $\mathrm{NaCl}$ homeostasis. Whether enhanced salt appetite contributes to extracellular volume expansion under PPAR $\gamma$ treatment, cannot be decided on the basis of our observations. Pioglitazone leads to enhanced food and, thus, salt intake, an effect presumably accounting for the enhanced urinary $\mathrm{Na}^{+}$elimination during pioglitazone treatment.

Leptin levels were elevated during pioglitazone treatment, to a similar extent, in both genotypes. The increase of leptin levels may point to an increase in white adipocyte mass, as leptin levels positively correlate with white fat mass [12]. This also implies that the observed body weight gain does not fully represent volume retention but also reflects an increase in white adipocyte mass. The SGK1independent effect of PPAR $\gamma$ agonists on white fat mass may have contributed to the gain of body weight.

In conclusion, PPAR $\gamma$ agonists upregulate expression of SGK1, which contributes to but does not fully account for extracellular volume expansion after treatment with these drugs.

Acknowledgments This work was supported by grants from DFG and BMBF (D.K., F.L., K.A.). The assistance of Miriam Reutelshoefer and Stefan Soellner in the performance of immunofluorescence is acknowledged. We also thank Andrea Janessa and Gisela Heck for the PCR measurements. We gratefully acknowledge the valuable discussions with Volker Vallon. 


\section{References}

1. Alvarez de la Rosa D, Zhang P, Naray-Fejes-Toth A, Fejes-Toth G, Canessa CM (1999) The serum and glucocorticoid kinase sgk increases the abundance of epithelial sodium channels in the plasma membrane of Xenopus oocytes. J Biol Chem 274:3783437839

2. Arteaga MF, Canessa CM (2005) Functional specificity of Sgk1 and Akt1 on ENaC activity. Am J Physiol Renal Physiol 289: F90-F96

3. Asher C, Wald H, Rossier BC, Garty H (1996) Aldosteroneinduced increase in the abundance of $\mathrm{Na}^{+}$channel subunits. Am J Physiol 271:C605-C611

4. Beaven SW, Tontonoz P (2006) Nuclear receptors in lipid metabolism: targeting the heart of dyslipidemia. Annu Rev Med 57:313-329

5. Benigni A, Zoja C, Tomasoni S, Campana M, Corna D, Zanchi C, Gagliardini E, Garofano E, Rottoli D, Ito T, Remuzzi G (2006) Transcriptional regulation of nephrin gene by peroxisome proliferator-activated receptor-gamma agonist: molecular mechanism of the antiproteinuric effect of pioglitazone. J Am Soc Nephrol 17:1624-1632

6. Blazer-Yost BL, Liu X, Helman SI (1998) Hormonal regulation of ENaCs: insulin and aldosterone. Am J Physiol 274:C1373-C1379

7. Blazer-Yost BL, Paunescu TG, Helman SI, Lee KD, Vlahos CJ (1999) Phosphoinositide 3-kinase is required for aldosteroneregulated sodium reabsorption. Am J Physiol 277:C531-C536

8. Blazer-Yost BL, Vahle JC, Byars JM, Bacallao RL (2004) Realtime three-dimensional imaging of lipid signal transduction: apical membrane insertion of epithelial $\mathrm{Na}(+)$ channels. Am J Physiol Cell Physiol 287:C1569-C1576

9. Busjahn A, Aydin A, Uhlmann R, Krasko C, Bahring S, Szelestei T, Feng Y, Dahm S, Sharma AM, Luft FC, Lang F (2002) Serum- and glucocorticoid-regulated kinase (SGK1) gene and blood pressure. Hypertension 40:256-260

10. Chen SY, Bhargava A, Mastroberardino L, Meijer OC, Wang J, Buse P, Firestone GL, Verrey F, Pearce D (1999) Epithelial sodium channel regulated by aldosterone-induced protein sgk. Proc Natl Acad Sci USA 96:2514-2519

11. Chinetti-Gbaguidi G, Fruchart JC, Staels B (2005) Role of the PPAR family of nuclear receptors in the regulation of metabolic and cardiovascular homeostasis: new approaches to therapy. Curr Opin Pharmacol 5:177-183

12. Correia ML, Haynes WG (2004) Leptin, obesity and cardiovascular disease. Curr Opin Nephrol Hypertens 13:215-223

13. Diakov A, Korbmacher C (2004) A novel pathway of epithelial sodium channel activation involves a serum- and glucocorticoidinducible kinase consensus motif in the $\mathrm{C}$ terminus of the channel's alpha-subunit. J Biol Chem 279:38134-38142

14. Farjah M, Roxas BP, Geenen DL, Danziger RS (2003) Dietary salt regulates renal SGK1 abundance: relevance to salt sensitivity in the Dahl rat. Hypertension 41:874-878

15. Firestone GL, Giampaolo JR, O'Keeffe BA (2003) Stimulusdependent regulation of the serum and glucocorticoid inducible protein kinase (Sgk) transcription, subcellular localization and enzymatic activity. Cell Physiol Biochem 13:1-12

16. Foldager N, Blomqvist CG (1991) Repeated plasma volume determination with the Evans Blue dye dilution technique: the method and a computer program. Comput Biol Med 21:35-41

17. Gonzalez-Rodriguez E, Gaeggeler HP, Rossier BC (2007) IGF-1 vs insulin: respective roles in modulating sodium transport via the PI-3 kinase/Sgk1 pathway in a cortical collecting duct cell line. Kidney Int 71:116-125

18. Gorson DM (1999) Significant weight gain with rezulin therapy. Arch Intern Med 159:99
19. Guan Y, Hao C, Cha DR, Rao R, Lu W, Kohan DE, Magnuson MA, Redha R, Zhang Y, Breyer MD (2005) Thiazolidinediones expand body fluid volume through PPARgamma stimulation of ENaCmediated renal salt absorption. Nat Med 11:861-866

20. Guan Y, Zhang Y, Davis L, Breyer MD (1997) Expression of peroxisome proliferator-activated receptors in urinary tract of rabbits and humans. Am J Physiol 273:F1013-F1022

21. Hill TW, Randall PJ (1976) A method for screening diuretic agents in the mouse: an investigation of sexual differences. J Pharm Pharmacol 28:552-554

22. Hong G, Lockhart A, Davis B, Rahmoune H, Baker S, Ye L, Thompson P, Shou Y, O'Shaughnessy K, Ronco P, Brown J (2003) PPARgamma activation enhances cell surface ENaCalpha via up-regulation of SGK1 in human collecting duct cells. FASEB J 17:1966-1968

23. Huang DY, Boini KM, Friedrich B, Metzger M, Just L, Osswald H, Wulff P, Kuhl D, Vallon V, Lang F (2006) Blunted hypertensive effect of combined fructose and high salt diet in gene targeted mice lacking functional serum and glucocorticoid inducible kinase SGK1. Am J Physiol Regul Integr Comp Physiol 290: R935-R944

24. Huang DY, Wulff P, Volkl H, Loffing J, Richter K, Kuhl D, Lang F, Vallon V (2004) Impaired regulation of renal $\mathrm{K}^{+}$elimination in the sgk1-knockout mouse. J Am Soc Nephrol 15:885-891

25. Huber SM, Friedrich B, Klingel K, Lenka N, Hescheler J, Lang F (2001) Protein and mRNA expression of serum and glucocorticoid-dependent kinase 1 in metanephrogenesis. Dev Dyn 221:464-469

26. Karalliedde J, Buckingham R, Starkie M, Lorand D, Stewart M, Viberti G (2006) Effect of various diuretic treatments on rosiglitazone-induced fluid retention. J Am Soc Nephrol 17:3482-3490

27. Klingel K, Hohenadl C, Canu A, Albrecht M, Seemann M, Mall G, Kandolf R (1992) Ongoing enterovirus-induced myocarditis is associated with persistent heart muscle infection: quantitative analysis of virus replication, tissue damage, and inflammation. Proc Natl Acad Sci USA 89:314-318

28. Lang F, Bohmer C, Palmada M, Seebohm G, Strutz-Seebohm N, Vallon V (2006) (Patho)physiological significance of the serumand glucocorticoid-inducible kinase isoforms. Physiol Rev 86:1151-1178

29. Lang F, Klingel K, Wagner CA, Stegen C, Warntges S, Friedrich B, Lanzendorfer M, Melzig J, Moschen I, Steuer S, Waldegger S, Sauter M, Paulmichl M, Gerke V, Risler T, Gamba G, Capasso G, Kandolf R, Hebert SC, Massry SG, Broer S (2000) Deranged transcriptional regulation of cell-volume-sensitive kinase hSGK in diabetic nephropathy. Proc Natl Acad Sci USA 97:8157-8162

30. Li Y, Wen X, Spataro BC, Hu K, Dai C, Liu Y (2006) hepatocyte growth factor is a downstream effector that mediates the antifibrotic action of peroxisome proliferator-activated receptorgamma agonists. J Am Soc Nephrol 17:54-65

31. Loffing J, Zecevic M, Feraille E, Kaissling B, Asher C, Rossier BC, Firestone GL, Pearce D, Verrey F (2001) Aldosterone induces rapid apical translocation of $\mathrm{ENaC}$ in early portion of renal collecting system: possible role of SGK. Am J Physiol Renal Physiol 280: F675-F682

32. Matsui J, Terauchi Y, Kubota N, Takamoto I, Eto K, Yamashita T, Komeda K, Yamauchi T, Kamon J, Kita S, Noda M, Kadowaki T (2004) Pioglitazone reduces islet triglyceride content and restores impaired glucose-stimulated insulin secretion in heterozygous peroxisome proliferator-activated receptor-gamma-deficient mice on a high-fat diet. Diabetes 53:2844-2854

33. Meneton P, Ichikawa I, Inagami T, Schnermann J (2000) Renal physiology of the mouse. Am J Physiol Renal Physiol 278:F339F351 
34. Naray-Fejes-Toth A, Canessa C, Cleaveland ES, Aldrich G, FejesToth G (1999) Sgk is an aldosterone-induced kinase in the renal collecting duct. Effects on epithelial $\mathrm{Na}^{+}$channels. J Biol Chem 274:16973-16978

35. Nikolaidis LA, Levine TB (2004) Peroxisome proliferator activator receptors (PPAR), insulin resistance, and cardiomyopathy: friends or foes for the diabetic patient with heart failure. Cardiol Rev 12:158-170

36. Nofziger C, Chen L, Shane MA, Smith CD, Brown KK, BlazerYost BL (2005) PPARgamma agonists do not directly enhance basal or insulin-stimulated $\mathrm{Na}(+)$ transport via the epithelial $\mathrm{Na}(+)$ channel. Pflugers Arch 451:445-453

37. Pourcet B, Fruchart JC, Staels B, Glineur C (2006) Selective PPAR modulators, dual and pan PPAR agonists: multimodal drugs for the treatment of type 2 diabetes and atherosclerosis. Expert Opin Emerg Drugs 11:379-401

38. Qayyum R, Adomaityte J (2006) A meta-analysis of the effect of thiazolidinediones on blood pressure. J Clin Hypertens (Greenwich) 8:19-28

39. Savkur RS, Miller AR (2006) Investigational PPAR-gamma agonists for the treatment of Type 2 diabetes. Expert Opin Investig Drugs 15:763-778

40. Vallon V (2003) In vivo studies of the genetically modified mouse kidney. Nephron Physiol 94:1-5

41. Vallon V, Huang DY, Grahammer F, Wyatt AW, Osswald H, Wulff P, Kuhl D, Lang F (2005) SGK1 as a determinant of kidney function and salt intake in response to mineralocorticoid excess. Am J Physiol Regul Integr Comp Physiol 289:R395-R401

42. Verreth W, De Keyzer D, Pelat M, Verhamme P, Ganame J, Bielicki JK, Mertens A, Quarck R, Benhabiles N, Marguerie G, Mackness B, Mackness M, Ninio E, Herregods MC, Balligand JL, Holvoet P (2004) Weight-loss-associated induction of peroxisome proliferator-activated receptor-alpha and peroxisome proliferatoractivated receptor-gamma correlate with reduced atherosclerosis and improved cardiovascular function in obese insulin-resistant mice. Circulation 110:3259-3269
43. von Wowern F, Berglund G, Carlson J, Mansson H, Hedblad B, Melander O (2005) Genetic variance of SGK-1 is associated with blood pressure, blood pressure change over time and strength of the insulin-diastolic blood pressure relationship. Kidney Int 68:2164-2172

44. Wong H, Ozalp Y, Lainesse A, Alpan RS (2004) In vivo bioequivalence of oral antidiabetic agents: pioglitazone tablets. Arzneimittelforschung 54:618-624

45. Wooltorton E (2002) Rosiglitazone (Avandia) and pioglitazone (Actos) and heart failure. CMAJ 166:219

46. Wulff P, Vallon V, Huang DY, Volkl H, Yu F, Richter K, Jansen M, Schlunz M, Klingel K, Loffing J, Kauselmann G, Bosl MR, Lang F, Kuhl D (2002) Impaired renal $\mathrm{Na}(+)$ retention in the sgk1knockout mouse. J Clin Invest 110:1263-1268

47. Yajima K, Hirose H, Fujita H, Seto Y, Fujita H, Ukeda K, Miyashita K, Kawai T, Yamamoto Y, Ogawa T, Yamada T, Saruta T (2003) Combination therapy with PPARgamma and PPARalpha agonists increases glucose-stimulated insulin secretion in $\mathrm{db} / \mathrm{db}$ mice. Am J Physiol Endocrinol Metab 284:E966-E971

48. Yang T, Michele DE, Park J, Smart AM, Lin Z, Brosius FC III, Schnermann JB, Briggs JP (1999) Expression of peroxisomal proliferator-activated receptors and retinoid $\mathrm{X}$ receptors in the kidney. Am J Physiol 277:F966-F973

49. Yoshimoto T, Naruse M, Nishikawa M, Naruse K, Tanabe A, Seki T, Imaki T, Demura R, Aikawa E, Demura H (1997) Antihypertensive and vasculo- and renoprotective effects of pioglitazone in genetically obese diabetic rats. Am J Physiol 272:E989-E996

50. Zafiriou S, Stanners SR, Saad S, Polhill TS, Poronnik P, Pollock CA (2005) Pioglitazone inhibits cell growth and reduces matrix production in human kidney fibroblasts. J Am Soc Nephrol $16: 638-645$

51. Zhang H, Zhang A, Kohan DE, Nelson RD, Gonzalez FJ, Yang T (2005) Collecting duct-specific deletion of peroxisome proliferatoractivated receptor \{gamma\} blocks thiazolidinedione-induced fluid retention. Proc Natl Acad Sci USA 102:9406-9411 